\title{
How Important is Oil in Nigeria's Economic Growth?
}

\author{
Anthony Enisan Akinlo \\ Department of Economics, Obafemi Awolowo University, Ile-Ife, Nigeria
}

Tel: 803-370-0756 E-mail: aakinlo@oauife.edu.ng

Received: February 8, 2012

Accepted: March 12, $2012 \quad$ Published: April 1, 2012

doi:10.5539/jsd.v5n4p165

URL: http://dx.doi.org/10.5539/jsd.v5n4p165

\begin{abstract}
This study assesses the importance of oil in the development of the Nigerian economy in a multivariate VAR model over the period 1960-2009. Empirical evidence shows that the five subsectors are cointegrated and that the oil can cause other non oil sectors to grow. However, oil had adverse effect on the manufacturing sector. Granger causality test finds bidirectional causality between oil and manufacturing, oil and building \& construction, manufacturing and building \& construction, manufacturing and trade \& services, and agriculture and building \& construction. It also confirms unidirectional causality from manufacturing to agriculture and trade \& services to oil. No causality was found between agriculture and oil, likewise between trade \& services and building \& construction. The paper recommends appropriate regulatory and pricing reforms in the oil sector to integrate it into the economy and reverse the negative impact of oil on the manufacturing sub sector.
\end{abstract}

Keywords: VAR model, Causality, Oil, Impulse response functions, Development, Nigeria

\section{Introduction}

In the last decades of the $20^{\text {th }}$ century, there was a counter-intuitive relationship between natural resources abundance and economic development (Auty, 2001). Developing countries with abundant natural resources underperformed compared with those that are deficient in natural resources (Ranis, 1991; Lal \& Myint, 1996; Sachs \& Warner, 1995, 1999; Auty, 2001). Specifically, the per capita incomes of the resource poor countries increased at rates two or three times faster than those of the resource abundant countries. The growth rate equally widened significantly since 1970s. The apparent paradox between natural resource abundance and economic growth as well as development has led to increasing research works into the so called resource curse (note 1) phenomenon.

Nigeria is a natural resource abundant country. In particular, over the past fifty years, the country's oil subsector has grown phenomenally. Both production and exports have increased enormously since commercial production in 1958. For example, crude oil production increased from 395.7 million barrels in 1970 to 776.01 million barrels in 1998. The Figure increased to 919.3 million barrels in 2006. The Figure however decreased to 777.5 million barrels in 2009. In the same way, crude oil exports increased from 139.5 million barrels in 1966 to 807.7 million barrels in 1979. The volume of crude oil exports dropped to 390.5 million barrels in 1987 but increased to 675.3 million barrels in 1998. The trend continued for most years after 2000. In the same way, oil revenue increased from $\$ 166.6$ million in 1970 to $\$ 1,591,675.00$ million and $\$ 6,530,430.00$ million in 2000 and 2008 respectively.

The huge revenues from oil, of course, presented net wealth and thus provided opportunity for increased expenditure and investment; however, the huge revenues complicated macroeconomic management and also made the economy highly oil dependent. Asides, in spite of the huge rents from oil, the economy still grapples with many problems including high and rising unemployment rate, declining manufacturing production, high and rising level of poverty and poor infrastructural development (note 2). The dismal performance of the Nigerian economy in the face of huge rents from oil has rekindled interest on the importance of oil in the growth and development process in Nigerian. Hence, the objective of the paper is to examine the contribution of the oil sector to the Nigerian economy over the period 1960-2009. Specifically, we examine whether or not cointegrating relationship exists between oil and other non oil sub sectors; and determine the direction of causality between the various sectors of the Nigerian economy.

The rest of paper is structured as follows. First, the second section provides a very brief summary of the theoretical perspectives on resource abundance and economic growth. The third section looks at the contribution of the oil sector to the Nigerian economy over the study period. The methodology adopted in the paper is 
discussed briefly in section 4 . The results of the estimation are presented in section 5 . The concluding section contains the summary of major findings and offers some policy prescriptions to integrate the oil sector into the national economy with a view to ensuring that it positively impacts the non oil sectors.

\section{Theoretical Perspectives on Resource Abundance and Growth}

This section provides a succinct summary of the theoretical literature on the nature of the relationship between resource abundance and development. The purpose is to first present a theoretical account of the malign and benign perspectives on the issue of resource abundance and economic progress. Then, the various channels through which oil may impact growth and development follow each perspective. However, the literature here should not be seen as a complete survey (note 3 ).

\subsection{The Benign Perspective: Natural Resource Abundance Beneficial to Growth}

The conventional wisdom before the late 80 s was that natural resources had positive effect on development (Rosser, 2006). This view was shared by many development theorists and neoliberal economists until the resurgence of new view in the 80 s that claimed that natural resource abundant was not a blessing to the developing countries. The basic argument of the benign perspective is that natural resource endowments would assist the developing countries to transit from the stage of underdevelopment to that of industrial 'take-off', as obtained in such countries as Britain, the United States and Australia.

Essentially, the various channels through which abundance of natural resources like oil sector could contribute to the economies of the oil producers have been identified in the literature. One, the huge revenues from oil enables the governments of the oil producing countries to spend and invest massively without recourse to taxation. Revenues from oil, if properly utilized, could serve as a "big push" for development. This channel is especially important for developing countries where paucity of capital often constitutes a major hindrance to growth and development. Moreover, the huge foreign exchange earnings from oil exports, apart from being used for importing raw material, intermediate and capital goods for production in the non oil sectors, could equally assist in boosting the foreign reserves of the oil exporting countries. The accumulation of foreign reserves can be seen as collateral which the oil producing economies can use in attracting foreign investment (Dooley et al., 2004). Moreover, such holding can be seen as a costly self-insurance strategy to smoothen vulnerability impacts of domestic and foreign shocks and to intervene in the foreign exchange market.

Oil sector can also contribute to development in the oil rich economies through provision of intermediate inputs to the rest of the economy. These intermediate inputs include crude oil, gas and liquid feed stocks, as well as oil and gas into the refining, petrochemical and electricity and energy intensive industries respectively (Al-Moneef, 2006). This channel is critical to growth and development in the developing countries. For instance, many outputs of the petrochemical industries are crucial to the development of the manufacturing industries. Likewise, provision of electricity and other basic utilities at favourable prices is of considerable importance in the process of growing and nurturing the service and manufacturing sub sectors.

Growth and development in the oil rich economies could be enhanced through the market contribution from oil. The market contribution relates to the demand by oil sector for various inputs of goods and services provided by local sources. Generally, as a result of oil production, refining and distribution, there is tendency for oil sector-related services to spring up. These oil sector-related services will not only provide opportunity for employment but also serve as sources of earnings for the operators.

Asides from the market contribution, the foreign investment (FDI) effect is very important. Oil activity often leads to inflow of foreign resources such as FDI and portfolio investment. Indeed, the bulk of FDI into majority of the countries that export oil are concentrated in the oil sector. The various channels through which FDI impacts growth and development in the recipient countries have been extensively discussed in the literature. Specifically, FDI inflows to developing countries not only help in increasing their stock of capital but may also assist in boosting labour productivity and incomes in the host country. Consequently, the levels of output, employment creation, and potential tax revenues are enhanced in the host countries (Ramirez, 2006) (note 4).

Empirically, few studies have been have provided results in support of the benign perspective on the impact of natural resources on economic growth and development. Some of these studies not only reported that resource abundance had positive impact on growth and development but also found that resource dependence had no adverse impact on growth (note 5).

\subsection{The Malign Perspective: Natural Resource Abundance Not a Blessing}

Sequel to the poor performance of most oil-rich countries in the $80 \mathrm{~s}$, the idea that natural resource abundance was a blessing to development was jettisoned by scholars. Critics argued that natural resource abundance is 
harmful to growth. Extensive literature exists on the various channels through which natural resources, especially oil, harms growth. The major transmission mechanisms include Dutch disease, volatility argument and inefficiency in resource allocation argument.

The Dutch disease simply says that an exogenous unexpected increase in foreign exchange revenues from natural resources, arising from increase prices or output, will precipitate a real exchange rate appreciation and thus a drop in output and employment in the non resource traded good sector, often manufacturing (note 6). The volatility argument is anchored on the fact that revenues from natural resources especially oil are very volatile, as they are driven by sharp and significant fluctuations in prices over relatively short periods of time. Consequently, in the face of fluctuating revenues, governments in the oil rich countries often find it extremely difficult to pursue a prudent fiscal policy. In addition, there is the general apprehension that windfall revenues arising from unanticipated high export prices would be used for consumption rather than being invested or at best invested on wasteful projects.

Moreover, emphasis is placed on the political economy considerations in explaining the nature of the relationship between natural resource abundance and economic growth. This view contends that large windfalls from the resource tends to generate and promote rent-seeking activities that involve corruption, voracity and civil conflict (note 7). Several empirical studies have confirmed the natural resource curse hypothesis.

Some other reasons why resource-rich countries might suffer resource curse are reduced returns to human investments, precipitated by natural resource exploitation (Gylfason, 2001a; b) and poor economic management that leads to inefficient resource allocation (Rosser, 2006).

All in all, while there are strong theoretical grounds to suspect a broad correspondence between natural resource abundance especially oil and low growth, the nature of the linkage is neither direct nor simple. Empirical literature has not provided conclusive answer to whether abundant natural resource is a curse or blessing (note 8). Even among studies that claimed the curse of natural resources actually exist, there is no agreement on what exactly drives the curse of the natural resources and on how it exactly plays out. This explains why further research should be focused on the causal link between natural resource abundance and growth in the resource rich economies.

\section{A Review of the Role of Oil in Nigeria}

The extractive sector in the Nigerian economy is large and extensive, with oil playing a dominant role. With nearly 37.2 billion barrels in reserves and $2.13 \%$ of global production, Nigeria has the world's tenth largest proven reserves (3.1\% of global reserves), and is among the top 10 oil producers. Since the discovery and production of oil Nigeria in 1958, the subsector has continued to play a major and dominant role in the Nigerian economy. In terms of output production and product contribution, oil witnessed steady progress throughout the period under consideration. Crude oil production increased from 1.9 million barrels in 1958 to 152.4 barrels in 1966 (see Table 1). Production of oil declined sharply in 1967 and 1968 as a result of the civil war. However, production increased from 395.7 million barrels in 1970 to 660.1 and 845.5 million barrels in 1975 and 1979 respectively. The increase in production witnessed during this period was precipitated by Middle East crisis and the 1973/74 oil embargo which caused a sharp reduction in world oil supply. The increased oil prices that the crisis generated helped to boost local oil production in the country. However, this was short-lived as the early 80s witnessed a glut in the international crude oil market owing to over-supply, which culminated in sharp drop in prices and eventual reduction in the production quotas by OPEC member countries.

Consequently, oil production in Nigeria dropped from 760.1 million barrels in 1980 to 535.9 and 383.3 million barrels in 1986 and 1987 respectively (note 9). The situation improved in the 90s as crude oil output rose from 383.3 million barrels in 1987 to $711.3,742.3$ and 772.9 million barrels in 1992, 1996 and 1998 respectively. The trend continued between the year 2000 and 2009. The cumulative crude oil production for the country increased from 20,575,881 million barrels in 2000 to 27,052, 0677 million barrels in the 2009. In general, crude oil production witnessed appreciable increase over the period under study.

The contribution of a product or sector to the national economy can be measured by its size in the GDP. The contribution of oil to the GDP in Nigeria increased steadily over the study period. As evidenced in Table 1 below, oil accounted for just 3.43 per cent of the GDP in 1965. The share of oil in the GDP increased from 9.27 per cent in 1970 to 19.37 per cent in 1975 . The Figure increased to 38.87 per cent in 2005. The share of oil in the GDP decreased marginally to 37.44 per cent in 2009 (note 10). Two main reasons can be offered for the increasing share of oil in GDP. The first is the discovery of oil in large quantity since early 70 s which led to massive oil production and export. The huge revenues from oil led to massive rural urban migration and the neglect of 
agriculture. The second reason is the natural tendency for share of agricultural sector to fall while non agricultural sector increases as the economy develops. This trend is as dictated by Engel's law (note 11).

Aside from the increased share of oil in GDP between 1960 and 2009, total oil exports increased phenomenally over the period. As shown in Table1, total oil exports in 1961 was $\$ 23.1$ million. The amount increased to $\$ 13$, 632.1 million in 1980. Oil exports value decelerated in the early 80s to reach a trough of $\$ 11,223.7$ million in 1985 owing to the general economic depression in the industrial nations and increased efficiency in energy use among other factors. However, the value of oil export assumed an upward trend in the 1990s. It increased from $\mathrm{N} 106,623.5$ million in 1990 to $\$ 1,920,900.4$ million, $\$ 7,140,578.9$ million and $\$ 8,543,261.2$ million in 2000 , 2005 and 2009 respectively.

As Table1 shows, the share of oil export in total exports in Nigeria increased from mere 6.65 per cent in 1961 to 97.03 per cent and 98.53 per cent in 1990 and 2005 respectively. The Figure decreased marginally to 96.73 per cent in 2009 following the deliberate government efforts at promoting non oil exports in the country. The high dependence on oil exports clearly shows that Nigeria is a monocultural economy (note 12). The country's non-oil exports were remarkably small. The share of non oil exports in the total exports was consistently less than 5 per cent over the period 1980-2009. No doubt, this has had a lot of dire consequences on the growth and development of the economy. If the export sector had been more diversified, the impact of the fluctuations in the international petroleum markets on the economy would have been minimal.

Sequel to high dependence on oil exports, the share of oil revenue in federally collected revenue increased phenomenally over the study period. It increased from 26.3 per cent in 1970 to 85.8 per cent in 2005 . The percentage dropped to 78.7 per cent in 2009 reflecting the increasing emphasis by government on non oil exports since mid 2000. The major implication of high government dependence on oil revenues was the fluctuation of government revenues in reflection of the value of oil exports in the country. This actually explains why government expenditure increased when the economy experienced boom and dropped when the economy slumped. In other word, government's fiscal policy became procyclical. Hence, government spending tends to exacerbate the ripples of oil shocks on the economy.

Another major area through which oil industry contributes to the Nigerian economy is in the attraction of FDI. Nigeria has attracted a lot of FDI particularly into the oil sector over the years and given the huge and bright potentials of this sector, it is likely that more new investments and reinvestments will be attracted. Several other channels through which oil has contributed to the Nigerian economy include provision of cheap and readily available source of energy, boosting of the foreign reserves and provision of employment (Odularo, 2008).

However, critics have contended that the direct effect of oil sector activity on non oil growth in Nigeria is rather limited. It is argued that the oil sector being an enclave sector has very little linkages with the other sectors in the economy. The oil sector does not offer much opportunity for employment in Nigeria because it is more capital than labor intensive industry. This is the reason why the significant expansion of the sector over the years has not led to a similar increase in job creation. Indeed at present, total level of employment in the Nigerian oil industry (including employment by ancillary firms) as a percentage of total modern sectors' employment in the country currently stands at 1.3 per cent. This is extremely low when viewed in terms of the size of the sector. Moreover, oil-related outflows including imports of capital equipments, income repatriated to foreign investors and amortization of FDI liabilities have been highly substantial in the country.

Besides, it is contended that the high dependence of the country on oil has posed significant challenges to formulation and implementation of economic policies in the economy. As global price changes are difficult to be fully addressed by domestic macroeconomic policies; the oil price volatility has induced macroeconomic challenges in the economy. As an illustration, whenever there is a fall in the price of oil, counter-cyclical fiscal action is constrained due to lack of other sources of revenue (note 13). Oil price changes often make the exchange rate volatile thereby encouraging undue short-term capital flows. More often than not, government action to mitigate this volatility often results in pro-cyclical monetary stance. In general, as a result of the limited capacity of small non-oil sector in counteracting swings in oil prices in response to policy actions, the effectiveness of macroeconomic policy is often constrained.

\section{Methodology}

This paper follows the multivariate cointegration VAR model developed by Johansen (1988) and Johansen \& Juselius $(1990 ; 1992)$. This approach is adopted as against other possible candidates for several reasons. One, no a priori assumption of exogeneity of variables is required. Two, vector auto regressive model allows each variable in the system not only to impact on itself but also on each other without the need to impose a theoretical structure on the estimates. Moreover, the approach affords us the opportunity of knowing not only how a given 
variable impact on itself but also on others through the use of variance decomposition (VDCs) and impulse response functions.

As our main goal is to ascertain whether oil and the rest of the economy are cointegrated, we divided the economy into five broad sectors namely: agriculture (agr), manufacturing (man), building \& construction (buc), oil (oil) and trade \& services (tsr) or $\mathrm{x}_{\mathrm{t}}=$ (oil, agr, man, buc, tsr)'. The VAR model as specified in Johansen and Juselius (1992) is given as (note 14):

$$
\Delta \mathrm{x}_{\mathrm{t}}=\sum_{i=1}^{p} \pi_{i} \Delta \mathrm{x}_{\mathrm{t}-\mathrm{i}}+\pi \mathrm{x}_{\mathrm{t}-1}+\Psi \mathrm{z}_{\mathrm{t}}+\varepsilon_{\mathrm{t}}
$$

where $\pi$ 's $(i=1, \ldots \ldots, \rho)$ are $(5 \times 5)$ matrices for the variables $\Delta \mathrm{x}_{\mathrm{t}-1}, \Delta \mathrm{x}_{\mathrm{t}}$ is a $(5 \mathrm{x} 1)$ column vector of the first differences of $x_{t} ; \pi$ is a $(5 \times 5)$ matrix for the variables $x_{t-1}$ which is a $(5 \times 1)$ column vector of lagged dependent variables, $\mathrm{z}_{\mathrm{t}}$ is a $(5 \times n)$ matrix containing $\mathrm{n}$ deterministic variables for each dependent variable; $\boldsymbol{\varepsilon}_{\mathrm{t}}$ is a $(5 \times 1)$ column vector of disturbance terms normally distributed with zero means and constant variances. In general, the time series characteristics of the variables determine whether vector-error corrections model (VECM) or an unrestricted vector autoregression model (VAR) will be specified. For cointegrated non-stationary variables, the correct specification is VECM. However, for uncointegrated non-stationary variables, the appropriate specification is an unrestricted VAR model.

Quarterly time series data of GDP indices of the five sectors over the 1960-2009 are used in setting up the VAR model. The 200 observations are quite adequate for VAR model. The data were compiled from the Central Bank of Nigeria (CBN) Statistical Bulletin 2009 edition.

\section{Empirical Results}

In general, a VAR specification requires the determination of the time series property of the data set. Consequently, we performed stationarity and cointegration tests on all the variables. All variables were expressed in natural logarithm so as to minimize the scale effect. To test for stationarity, we employed two main tests namely; the Augmented Dickey Fuller (Dickey \& Fuller, 1979) and KPSS Kwiatkowski-Phillips-Schmidt-Shin (1992) both with a constant and a deterministic trend. Thus the limitation of the ADF statistic in deciding whether $\varphi=1$ or $\varphi=0.98$, in a model like: $X_{t}=\mu+\varphi X_{t-1}+\varepsilon_{t}$ is remedied by the application of the KPSS statistic simultaneously. The Akaike Information Criterion (AIC) and Schwartz Criterion (SC) both indicated optimal lag length of four. The results in Table 2 clearly reveal that all the variables are integrated of order one, I (1).

As the variables are stationary at first difference, we therefore tested for cointegration using the Johansen and Juselius (1990) method (note 15). The results of $\lambda$-maximum and the trace tests are as reported in Table3. The third and the fourth columns report maximum eigenvalue statistics and critical values respectively, while the fifth and the sixth columns show the trace statistics and its critical values at 95 per cent respectively. The results in Table 3 show that the null hypothesis of no cointegration relationship can be rejected at the 5 per cent level using either $\lambda$-maximum or trace test statistics. The trace test suggests three cointegrating vectors while the $\lambda$-maximum test suggests one cointegrating vector. This simply means that long run relationship exists amongst the five sub sector. This result suggests that these five variables (sub-sectors) could not have moved too far away from each other, thereby displaying a co-movement phenomenon for agriculture, manufacturing, oil, building \& construction and trade \& services in Nigeria over this sample period.

The cointegrating vectors (normalized successively on oil, agr, man, buc and tsr) are as shown in Table 4 respectively (note 16). The coefficients of the variables imply the elasticities of the variables, since all the variables are in logarithms. Some general observations are discernible from the results in Table 4. One, it is interesting to notice that inter-sectoral relationships can be either negative or positive. The coefficient of oil variable is positive in all the models except in the manufacturing model. The coefficient of oil variable is significant in all the models. Two, the coefficient of agriculture is not only positive but also significant in all the models. Three, negative coefficient of oil variable in the manufacturing model lends credence to the 'Dutch disease' argument (note 17). A positive trend coefficient for building \& construction and trade \& services suggest that these two sectors experienced much faster growth than the aggregate growth trend of economy. The negative trend coefficients for agriculture, manufacturing and oil suggest that these sectors lagged behind the economy's aggregate growth rate. The neglect of agriculture and manufacturing by the various governments in the country over the years is clearly reflected in the results. The negative trend coefficient in oil equation might possibly reflect the disruptions in the oil production precipitated by the activities of the Niger Delta militants over the period under consideration (note 18). 
As postulated by Engle and Granger (1987), cointegrated variables must have an error correction representation whereby an error correction term is incorporated into the model. Essentially, such a formulation helps to reintroduce the information lost in the process of differencing and thus allowing for long-run equilibrium as well as short run dynamics. Therefore, a Vector Error Correction Model (VECM) was formed and estimated to determine between oil, manufacturing, building \& construction, agriculture and trade \& services. Table 5 presents the estimated results of VECM. Each of the error correction terms is significant except for agriculture. Moreover, except for manufacturing each of the error terms denoted as $\xi_{\mathrm{t}-1}$ are negative. This seems to suggest that active channels of causality exist among the variables. The summary of the direction of causality is as shown in Table 6.

The results from Table 6 show that no causality exists between oil and agriculture [agr $<\neq>$ oil]. Also, there is no evidence of causality between building \& construction and trade \& services [buc $<\neq>$ tsr]. The results show a case of unidirectional causality between manufacturing and agriculture [manufacturing $\Rightarrow$ agriculture], agriculture and trade \& services (agr $=>$ tsr], and trade \& services and oil [tsr $=>$ oil]. Finally, a bidirectional causality was found between manufacturing and trades \& services [man $<=>$ tsr], agriculture and building \& construction [agr $<=>$ buc], oil and manufacturing [oil $<=>$ man], building \& construction and oil [buc and oil] and manufacturing and building \& construction [man $<=>$ buc]. Essentially, the results from the causality test are summarized as shown in Figure 1.

As it has been noted in the literature, individual coefficients from error-correction model are difficult to interpret in the case of the vector auto-regressive model. Consequently, the dynamic properties of the model are analyzed by examining the impulse response functions (IRFs) and the variance decompositions (VDCs) (note 19). The impulse response functions trace the dynamic responses to the effect of shock in one variable not only upon itself but also upon on all other variables. These impulse response functions are plotted in Figure 2. It can be seen clearly from Figure 2 that the response of agriculture to a one standard deviation (SD) innovation in oil is slightly positive in the short run with some tendency to decline before assuming constant level in the long run. A one standard deviation shock to oil shows negative impact on the manufacturing sub sector turn positive in the 2nd period but becomes negative after the third periods. This no doubt provides evidence in support of the resource curse hypothesis. The response of building \& construction to a one standard deviation (SD) innovation in oil is sharply negative in the short run but the impact turns positive in the medium term before assuming constant level in the long run. In the same way, the response of trade and services (tsr) to a one SD innovation in oil is negative and after two periods becomes positive though the increase is not dramatic.

Aside from IRFs, this study traces the variance decomposition (VDC) of each variable over a ten period. The VDC provides information about the relative importance of each random (one-standard deviation) shock to the endogenous variables in the VECM. The summary of the results is as reported in Table 7 . The results show that relatively low proportion of the variance in agriculture shocks is attributable to shocks in oil, and other sub sectors. The results suggest, that after 10 years, a unitary shock in the other sub sectors explains about 5 per cent of the accumulated forecast error variance of agriculture. However, a good proportion of the variance in manufacturing is attributable to shocks in agriculture, and building \& construction. In the same way, agriculture and oil account for shocks in building \& construction. A good proportion of the variance in trade \& services is attributable to shock in agriculture, oil and building \& construction. Agriculture accounts for shocks in oil. In general, oil accounts for shocks in building \& construction, trade \& services, but not nearly as much in manufacturing. The importance oil shock to agriculture is highly negligible.

\section{Conclusions}

This paper has examined the role of oil in the development of the Nigerian economy. Several major findings were obtained from the analysis. First, evidence from the descriptive analysis reported in section 2 suggests that crude oil production has increased substantially in Nigeria since the discovery of oil in 1958. The share of oil in the total GDP has increased phenomenally over the period 1958 to 2009. In the same way, oil exports increased from mere 1.9 million barrels in 1958 to an average of 2012.5 thousand barrels in 2009. Second, the paper adopted a multivariate cointegration analysis using the VAR model developed in Johansen \& Juselius (1990; 1992). The evidence from estimated econometric model suggests that the variables included are stationary at first differences. Hence, they are integrated of order one. The Johansen cointegration test shows that there is cointegration and hence, confirmed the existence of long run equilibrium relationship between the variables included in the model. This means that the economic sectors tend to move together in the long run. However, the results show that oil negatively affected manufacturing sub sector during the study period. 
The results provide evidence which suggests that there exists bidirectional causality between manufacturing and oil, building \& construction and oil, manufacturing and trade \& services, oil and building \& construction, and manufacturing and building \& construction. No evidence of causality was found between agriculture and oil as well as between building and construction and trade and services; a unidirectional causality from trade \& services to oil and manufacturing to agriculture. The reported IRFs and VDCs suggest that oil accounts for shocks in building \& construction, and trade \& services, but not nearly as much in manufacturing. Its role in agriculture is highly negligible. A good proportion of the variances in manufacturing, oil, building \& construction, and trade \& services are attributable to shock in agriculture. The importance of building and construction shocks to trade and services is apparent in contrast to the reverse case where shocks to building and construction are almost negligible in explaining shocks to trade and services.

From a policy perspective, the finding that the five economic sectors are cointegrated is an indication that increased oil activity could impact on the other non oil sub sectors. However, to ensure that oil continues to foster better growth and development there is the need to focus on three major areas. These are sustenance of increased investment inflows to the oil sector, stimulation of local labour and capital and institution of appropriate reforms to enhance efficiency and transparency. These reforms will entail institution of appropriate pricing policy in the oil sub sector and elimination of corruption in the sector. In order to eliminate the current massive corruption in the sector, there is need to deregulate the sector to allow private initiatives. In the meantime, the government should ensure that the various refineries are reactivated to produce refined products for local consumption and export. This will assist in the integration of the oil sub sector into the economy through increased employment and positive value added.

Moreover, the direct benefits of stronger oil activity would be more in the other non oil subsectors if the negative impact of oil activity on the manufacturing in the long run is reversed. However, if the manufacturing sub sector is to benefit positively from oil activity, there is the need to increase investments in the sub sector. Increased investments in the sub sector will come in form of infrastructural development, education and research. Increased investment in the manufacturing sub sector will assist in eliminating economies of scale and other distortions which make loss of manufacturing capacity costly to reverse, in the face of dwindling oil revenues.

\section{Acknowledgements}

Author would like to thank the Editor and two anonymous referees for valuable comments and suggestions to improve the quality of the paper.

\section{References}

Aitken, B. G. H., \& Harrison, A. (1997). Spillovers, foreign investment, and export behavior. Journal of International Economics, 43, 103-132. http://dx.doi.org/10.1016/S002-1996(96)1464-x

Al-Moneef, M. (2006). The contribution of the oil sector to Arab Economic development. OFI Pamphlet Series 34.Vienna: Austria.

Auty, R. M. (2001). Introduction and Overview. In Auty, R. S. (Ed.), Resource Abundance and Economic Development ( $1^{\text {st }}$ ed., pp.3-16). Oxford: Oxford University Press.

Ambler, S. (1989). Does money matter in Canada? Evidence from a vector error-correction model. Review of Economics and Statistics, 71, 651-658. http://dx.doi.org/10.2307/1928107

Brunnschweiler, C. N. (2008). Cursing the blessings? Natural resource abundance, institutions, and economic growth, World Development, 36, 399-419. http://dx.doi.org/10.1016/j.worlddev.2007.03.004

Brunnschweiler, C. N. (2009). Oil and growth in transition countries. CER-ETH Economic Working Paper 108. [Online] Available: http://www.oxcarre.ox.ac.uk/Research paper/p200929pdf

Brunnschweiler, C. N., \& Bulte, E. H. (2008). The resource curse revisited and revised: A tale of paradoxes and red herrings. Journal of Environmental Economics and Management, 55, 248-264. http://dx.doi.org/10.1016/j.jeem.2007.08.004

Central Bank of Nigeria. (2009). Central Bank of Nigeria statistical bulletin. 20, Central Bank of Bank of Nigeria, Abuja.

Collier, P., \& Hoeffler, A. (1998). On economic causes of civil war. Oxford Economic Papers, 50, 563-573. http://dx.doi.org/10.1093/oep/50.4.563

Collier, P., \& Hoeffler, A. (2004). Greed and grievance in civil war. Oxford Economic Papers, 56, 563-595. http://dx.doi.org/10.1093/oep/gpf064 
Corden, P., \& Neary, J. P. (1982). Booming sector and de-industrialization in a small open economy. The Economic Journal, 92, 825-848. http://dx.doi.org/10.2307/2232670

Dickey, D., \& Fuller, W. (1981). Likelihood ratio statistics for autoregressive time series with a unit root. Econometrica, 49, 1057-1075. http://dx.doi.org/10.2307/1912517

De Mello, L. R. Jr. (1997). Foreign direct investment in developing countries and growth: A selective survey. Journal of Development Studies, 43, 1-34. http://.doi:10.1080/00220389708422501

Dooley, M., Folkerts-Landu, D., \& Garber, P. (2003). An essay on the revised Bretton Woods system. Working Paper No. 9971, Cambridge, M. A. NBER. [Online] Available: http://www.nber.org/papers/w9971

Engle, R. F., \& Granger, C. W. J. (1987). Cointegration and error correction: Representation, estimation, and testing. Econometrica, 55, 251-73. http://dx.doi.org/10.2307/1913236

Esfahani, H. S., Mohaddes, K., \& Pesaran, M. H. (2009). Oil exports and the Iranian economy. IZA Discussion Paper 4537. [Online] Available: www.CESifo-group.org/wp

Fearon, J. D., \& Laitin, D. D. (2003). Ethnicity, insurgency, and civil war. American Political Science Review, 97, 75-90. http://dx.doi.org/10.1017/S0003055403000534

Gylfason, T. (2001a). Natural resources, education and economic development. European Economic Review, 45, 847-859. http://dx.doi.org/10.1111/1467-9485.00215

Gylfason, T. (2001b). Nature, power, and growth. Scottish Journal of Political Economy, 48, 558-588.

Harris, R. I. D. (1995). Using Cointegration Analysis in Econometric Modeling. London: Harvester Wheatsheaf.

Huang, T. Jr. (2004). Spillovers from Taiwan, Hong Kong, and Macau investment and from other foreign investment in Chinese indistries. Contemporary Economic Policy, 22, 13-25. http://dx.doi.org/10.1093/cep/byn002

Jerome, A., Busari, D., \& Adjibolosoo, S. (2009). Oil and growth in Africa: A comparative analysis. [Online] Available: http//www.africametrics.org/documents/conferences09_pdf

Johansen, S. (1988). Statistical analysis of cointegration vectors. Journal of Economic Dynamics and Control, 12, 231-54. http://dx.doi.org/10.1016/0165-1889(88)90041-3

Johansen, S., \& Juselius, K. (1990). Maximum likelihood estimation and inferences on cointrgation-with applications to the demand for money. Oxford Bulletin of Economics and Statistics, 52, 169-210. http://dx.doi.org/10.1111/j.1468-0084.1990.mp52002003.x

Johansen, S., \& Juselius, K. (1992). Testing structural hypotheses in a multivariate cointegration analysis of the PP and UIP for UK. Journal of Econometrics, 53, 211-244. http://dx.doi.org/10.1016/0304-4076(92)90086-7

Kim, H. (2009). Generalized impulse response analysis: General or extreme? MPRA Paper No. 17014.

Krugman, P. (1987). The narrow moving band, the dutch disease and the competitive consequences of Mrs Thatcher: Notes on trade in the presence of dynamic scale economies. Journal of Development Economics, 27, 41-55. http://dx.doi.org/10.1016/0304-3878(87)90005-8

Kwiatkowski, D., Phillips, P. C. B., Schmidt, P., \& Shin, Y. (1992). Testing the null hypothesis of stationary against the alternative of a unit root. Journal of Econometrics, 54, 159-178.

Lal, D., \& Myint, H. (1996). The Political Economy of Poverty, Equity and Growth. Oxford: Clarendon Press.

Lane, P., \& Tornell, A. (1996). Power, growth and the voracity effect. Journal of Economic Growth, 1, 213-241. http://dx.doi.org/10.1007/BF00138863

Leite, C., \& Weidmann, J. (1999). Does mother nature corrupt-natural resources, corruption and economic growth. IMF Working Paper 99/85, Washington D. C.: International Monetary Fund.

Muscatelli, V. A., \& Hurn, S. (1992). Cointegration and dynamic time series models. Journal of Economic Surveys, 6, 1-43. http://dx.doi.org/10.1111/j.1467-6419.1992.tb00142.x

Neary, J. P., \& van Wijnbergen, S. J. G. (1986). Natural Resources and the Macroeconomy. MIT Press, Cambridge, MA.

Odularo, G. O. (2008). Crude oil and the Nigerian economic performance. Oil and Gas Business. [Online] Available: http://www.ogbus.ru/eng/ 
Pesaran, M. H., \& Shin, Y. (1998). Generalised impulse response analysis in linear multivariate models. Economics Letters, 58, 17-29. http://dx.doi.org/10.1016/S0165-1765(97)00214-0

Ram, R., \& Zhang, K. H. (2002). Foreign direct investment and economic growth: Evidence from cross-country data for the 1990s. Economic Development and Cultural Change, 51, 205-215. http://dx.doi.org/10.1086/345453

Ramirez, M. D. (2006). Is foreign direct investment beneficial for Mexico? An empirical analysis, 1960-2001. World Development, 34, 802-817. http:dx.doi:10:1016/j.worlddev.2006.01.001

Ranis, G. (1991). Towards a model of development. In L. B. Krause and K. Kihwan (Eds.), Liberalization in the process of economic development (pp.59-101). Berkeley, CA: University of California Press.

Renote, E. R. Jr. (2001). Two decades of vector autoregressive (var) modeling. Philippine Review of Economics, $38,83-121$.

Rosser, A. (2006). The political economy of the resource curse: A literature survey. IDS Working Paper 268. www.ids.ac.uk/ids/bookshop

Sachs, J. D., \& Warner, A. M. (1995). Natural resource abundance and economic growth. NBER Working Paper No. 5398.

Sachs, J. D., \& Warner, A. M. (1999). The big push, natural resource booms and growth. Journal of Development Economics, 59, 43-76. http://dx.doi.org/10.1016/S0304-3878(99)00005-X

Tornell, A., \& Lane, P. R. (1999). The voracity effect, American Economic Review, 89, 22-46. http://dx.doi.org/10.1257/aer.89.1.22

\section{Notes}

Note 1. The resource curse argument came to front burner as a result of the influential research of Sachs and Warner $(1995 ; 1999)$. They indeed popularized primary resource exports over GDP as a measure of resource wealth.

Note 2. The Nigerian economy has been grappling with economic, social and political problems since late 70s. Government attempt at solving these problems led to the implementation of structural adjustment programme in 1986. Several other measures have been implemented since then without much success.

Note 3. Here, we only provided a brief summary of the theoretical relationships between resource abundance and economic growth and development for two main reasons. The first, is the need to conserve space. The second is that a number of studies have examined the theoretical relationships between resource abundance and economic growth. Some of these earlier studies include Corden \& Neary (1982); Krugman (1987); Neary \& Wijnbergen (1986); Leite \& Weidmann (1999); Collier \& Hoeffler (2004) among others.

Note 4. Indeed, several studies have demonstrated empirically the positive impact of FDI on growth in the host countries. See the works of De Mello Jr. (1997); Huang (2004); Ram \& Zhang (2002); and Aitken \& Harrison (1997).

Note 5. Empirical evidence in support of this argument can be found in the works of Brunnschweiler and Bulte (2008) and Brunnschweiler (2009) among others.

Note 6. However, it is being argued in the literature that this on its own should not generate adverse long run implications for the entire economy. This is because once the revenues from the resource are diminished or vanished totally; the economy is expected to re-adjust except there are important non-convexities or rigiditie/imperfections in the economy. As an illustration, the loss of manufacturing capacity will be very costly to reverse if the manufacturing sector is subject to economies of scale or learning by doing. (Esfahani et al., 2009).

Note 7. Details of this arguments can be found in the works of Mauro 1995, Leite \& Weidmann (1999); Lane \& Tornell (1996); Tornell \& Lane (1999).

Note 8. For example, study by Jerome et al (2006) showed that oil had non significant positive effect on growth in seven oil producing African countries while Odularo (2008) found that oil did not contribute significantly to growth in Nigeria between 1970 and 2005. However, study by Brunnswhweiler $(2008,2009)$ found that oil had significant positive effects on growth in 27 selected newly independent states of the former Soviet Union (FSU) and Central and Eastern Europe (CEE). Likewise, Al-Moneef (2006) provided evidence of positive impact of oil on the growth and development of the Arab countries; oil and non oil exporting countries inclusive. 
Note 9. Other factors that were responsible for the low production levels in the 80 s included general economic depression in the industrial nations, increased efficiency in energy use, rigorous conservation efforts and successful substitution of oil with other forms of energy in major oil importing countries, as well as the exploration and development of competing oil fields in North Sea, Alaska and Mexico.

Note 10. Although, the share of oil in the total GDP has increased over the years, the sector has had a disproportionately low contribution to the GDP and overall economic transformation of the country. Assessing this disconnect is key to securing long term supplies in Nigeria.

Note 11. Engel's law states that consumers tend to spend a lower proportion of incremental income on food product as personal income grows as a result of economic development. Consequently, the share of agriculture in the GDP will fall, while that of non oil, especially manufacturing will increase.

Note 12. As a matter of fact, of the twenty most oil dependent countries in the world, Nigeria ranked as the highest. Government efforts at diversifying the economy have not yielded results due mainly to poor economic management and corruption in the country.

Note 13. This risks could have been somewhat mitigated if the Nigerian government had adopted prudent policy of judiciously investing or saving the bulk of the oil proceeds. Unfortunately, the reverse was the case as government, over the years, wasted bulk of the oil proceeds on white elephant projects that dotted the map of the country.

Note 14. The VAR methodology has been widely adopted in the literature to warrant detailed description here. Therefore, we only provide a sketch of the technique in this paper. For detailed explanations and reviews of the technique one can consult the work of Ambler, 1989; Muscatelli \& Hurn (1992); Harris (1995) and Renote, Jr. (2001) among others.

Note 15. The Johansen approach was preferred above the Engle \& Granger (1987) method because it is capable of determining the number of cointegrating vectors for any given number of non-stationary series (of the same order). Its application is appropriate in the presence of more than two variables, and more importantly, Johansen (1988) has demonstrated that the likelihood ratio tests in this procedure (unlike the DF, ADF tests) have well-defined limiting distributions.

Note 16. The normalization of cointegrating vector on the each sector is carried out to be able to determine the impact of oil variable on the other sectors in the long run.

Note 17. One other possible reason for the negative impact of oil on the manufacturing sector may be the enclave nature of the oil sub sector. For some years now, the quantity of domestic refining has fallen following the collapse of the refineries; crude oil is just leaving the country without touching the soil. Moreover, the high tariff placed by high income countries on processed petroleum products than crude oil to protect their own manufacturing firms against competition might have inhibited the development of the down stream industries that add value to petroleum. Finally, the oil boom of the 1970s caused the exchange rate to be overvalued thereby making Nigerian manufacturing exports less competitive on the international market.

Note 18. Since 1990, the Niger Delta region has engulfed in many political violence. The local ethnic minorities have been agitating for a greater share of oil revenues. Government has made efforts since independence to address the demands of the minorities by setting up various commissions and more recently the Amnesty programme for Niger Delta militants. Yet, the community demands for greater autonomy, and greater control over oil revenues, have not abated significantly. Local groups continue to obstruct the activities of oil firms, in order to press their demands.

Note 19. We are aware of the fact that Cholesky decomposition can be affected by the ordering of the variables and the possibility of correcting it by using generalized decomposition process (GIRF) proposed by Pesaran \& Shin (1998). But, as demonstrated recently by Kim (2009), GIRF may yield quite misleading economic inferences. According to Kim (2009), the method yields a set of response functions that are based on extreme identifying assumptions that contradict each other, unless the covariance matrix is diagonal. However, to check the consistency of our estimates using Cholesky decomposition, we reversed the order of the first and the last variables and .re-estimated the model. The results obtained were not significantly different from the one reported here. Hence, we do not find necessary to report them here. 
Table 1. Oil output, exports and revenue in Nigeria, 1960-2009

\begin{tabular}{ccccccc}
\hline Year & $\begin{array}{c}\text { Production } \\
(\mathrm{bm})\end{array}$ & Oil Revenue & Oil/Total Revenue (\%) & Oil/GDP (\%) & $\begin{array}{c}\text { Oil Export } \\
(\text { Nm) }\end{array}$ & $\begin{array}{c}\text { Oil Export/ } \\
\text { Total Export } \\
(\%)\end{array}$ \\
\hline 1961 & 16.80 & nil & Nil & 0.9 & 23.1 & 6.65 \\
1965 & 150.3 & nil & Nil & 3.43 & 136.2 & 25.37 \\
1970 & 395.7 & 166.4 & 26.3 & 9.27 & 509.6 & 57.54 \\
1975 & 660.1 & 4271.5 & 77.5 & 19.37 & 4563.1 & 92.64 \\
1980 & 760.1 & 12353.2 & 81.1 & 28.48 & 13632.1 & 96.09 \\
1985 & 507.5 & 10923.7 & 72.6 & 16.75 & 11223.7 & 95.76 \\
1990 & 660.6 & 71887.1 & 73.3 & 37.46 & 106623.5 & 97.03 \\
1995 & 712.3 & 324547.6 & 70.6 & 39.65 & 927565.3 & 97.57 \\
2000 & 797.9 & 1591675.8 & 83.5 & 47.72 & 1920900.4 & 98.72 \\
2005 & 919.3 & 4762400 & 85.8 & 38.87 & 7140578.9 & 98.53 \\
2009 & 759.2 & 3191938 & 78.7 & 37.44 & 8543261.2 & 96.73 \\
\hline
\end{tabular}

Source: (a) Central Bank of Nigeria, Statistical bulletin, various years

Table 2. Nigeria: Unit root tests for stationarity with constant and linear trend, 1960-2009

\begin{tabular}{ccccc}
\hline Series & \multicolumn{2}{c}{ ADF } & \multicolumn{2}{c}{ KPSS } \\
\hline & Level & $1^{\text {st }}$ difference & Level & $1^{\text {st }}$ difference \\
\hline ln agr(constant) & -0.691 & -6.221 & 3.789 & 0.055 \\
(constant \& linear) & -2.022 & -6.205 & 0.481 & 0.054 \\
ln man (constant) & -1.463 & -4.875 & 3.594 & 0.030 \\
(constant \& linear) & -1.484 & -4.979 & 0.809 & 0.016 \\
ln oil (constant) & -2.309 & -6264 & 3.485 & 0.374 \\
(constant \& linear) & -1.159 & -6.609 & 0.947 & 0.026 \\
ln buc (constant) & -1.362 & -5.002 & 3.339 & 0.111 \\
(constant \& linear) & -1.586 & -5.054 & 0.762 & 0.072 \\
ln tsr (constant) & -1.031 & -5.151 & 3.719 & 0.088 \\
(constant \& linear) & -2.016 & -5.163 & 0.729 & 0.072 \\
\hline
\end{tabular}

Note:Critical values for ADF are: $-3.46,-2.88$, and -2.57 (constant only); -4.01, -3.43, and -3.14 (constant and linear) at $1 \%, 5 \%$ and $10 \%$ level of significance respectively. However, the critical values for KPSS test are:0.739, 0.463 and 0.347 (constant only), $0.216,0.146$ and 0.119 (constant and linear) at 1\%, 5\% and 10\% level of significance, respectively.

Table 3. Nigeria: Johansen Co-integration Test (with a linear Trend) where is the Number of ointegrating vectors

\begin{tabular}{c|ccccc}
\hline Null & Alternative $r$ & $\lambda$-max & Critical values $^{a}$ & Trace & Critical values $^{a}$ \\
\hline 0 & 1 & 95.03 & 40.08 & 179.58 & 95.75 \\
$<1$ & 2 & 31.55 & 33.88 & 84.55 & 69.82 \\
$<2$ & 3 & 27.09 & 27.58 & 53.00 & 69.82 \\
$<3$ & 4 & 14.66 & 21.13 & 25.90 & 29.80 \\
$<4$ & 5 & 9.53 & 14.26 & 11.25 & 15.49 \\
$<5$ & 6 & 1.72 & 3.84 & 1.72 & 3.84 \\
\hline
\end{tabular}

Note: Critical values at $95 \%$ level 
Table 4. Normalized cointegrating vector; coefficients normalized on agr, man, buc, tsr and oil respectively

\begin{tabular}{|c|c|c|c|c|c|}
\hline agr & oil & man & buc & tsr & trend \\
\hline-1.000 & 0.513 & 0.276 & -0.184 & -0.122 & -3.506 \\
& $(3.20)^{* * *}$ & $(1.03)$ & $(-0.99)$ & $(-0.38)$ & $(-6.69)^{* * *}$ \\
\hline man & oil & agr & buc & tsr & trend \\
\hline-1.000 & -1.859 & 3.625 & 0.667 & 0.442 & -12.71 \\
& $(4.11)^{* * *}$ & $(3.17)^{* * *}$ & $(0.595)$ & $(0.22)$ & $\left(-7.12^{* * *}\right.$ \\
\hline buc & oil & agr & man & tsr & trend \\
\hline-1.000 & 2.788 & 5.438 & 1.50 & -0.663 & 19.09 \\
& $(3.78)^{* * *}$ & $(5.15)^{* * *}$ & $(0.99)$ & $(-0.47)$ & $(6.68)^{* * *}$ \\
\hline tsr & oil & agr & man & buc & trend \\
\hline-1.000 & 4.205 & 8.202 & 2.26 & -1.508 & 28.75 \\
& $(3.20)^{* * *}$ & $(5.20)^{* * *}$ & $(1.01)$ & $(-1.25)$ & $(4.14)^{* * *}$ \\
\hline oil & agr & man & buc & tsr & trend \\
\hline-1.000 & 1.951 & -0.538 & 0.359 & 0.238 & -6.838 \\
& $(3.07)^{* * *}$ & $(-1.28)$ & $(0.61)$ & $(0.22)$ & $(-6.63)^{* * *}$ \\
\hline
\end{tabular}

Note: The $t$ ratios are in parenthesis.

Table 5. Nigeria: VEC model estimates

\begin{tabular}{|c|c|c|c|c|c|}
\hline Equation & $\Delta a g r_{t}$ & $\Delta \operatorname{man}_{t}$ & $\Delta o i l_{t}$ & $\Delta b u c_{t}$ & $\Delta t s r t$ \\
\hline \multirow{2}{*}{$\xi_{\mathrm{t}-1}$} & -0.0033 & 0.0732 & -0.0252 & -0.0107 & $-(0.126$ \\
\hline & $(-0.265)$ & $(9.467)$ & $(-4.304)$ & $(-3.663)$ & $(-4.367)$ \\
\hline \multirow[b]{2}{*}{$\alpha$} & 0.0287 & 0.0401 & 0.0574 & 0.0258 & 0.0347 \\
\hline & $(1.348)$ & $(1.248)$ & $(2.304)$ & $(2.067)$ & $(2.822)$ \\
\hline \multirow{2}{*}{$\Delta \operatorname{agr}_{\mathrm{t}-1}$} & -0.4843 & 0.4904 & 0.0066 & -0.0725 & -0.0318 \\
\hline & $(-5.399)$ & $(3.543)$ & $(0.063)$ & $(-1.384)$ & $(-0.616)$ \\
\hline \multirow{2}{*}{$\Delta \mathrm{agr}_{\mathrm{t}-2}$} & -0.2781 & 0.1427 & -0.0067 & -0.0353 & -0.0227 \\
\hline & $(-3003)$ & (0.999) & $(-0.062)$ & $(-0.653)$ & $(-0.426)$ \\
\hline \multirow{2}{*}{$\Delta \operatorname{man}_{\mathrm{t}-1}$} & -0.0382 & -0.0784 & -0.1430 & 0.0605 & -0.0076 \\
\hline & $(-0.504)$ & $(-0.669)$ & $(-1.613)$ & (1.364) & $(-0.173)$ \\
\hline \multirow{2}{*}{$\Delta \mathrm{man}_{\mathrm{t}-2}$} & -0.0739 & 0.1940 & -0.0507 & 0.0978 & 0.0108 \\
\hline & $(-1.508)$ & $(2.565)$ & $(-0.886)$ & $(3.418)$ & $(0.382)$ \\
\hline \multirow{2}{*}{$\Delta$ oil $_{t-1}$} & 0.0551 & 0.0665 & -0.3469 & -0.0061 & 0.0095 \\
\hline & $(0.684)$ & $(0.535)$ & $(-3.687)$ & $(-0.045)$ & $(0.109)$ \\
\hline \multirow{2}{*}{$\Delta$ oil $_{t-2}$} & 0.0288 & 0.0404 & -0.0912 & 0.0061 & 0.0095 \\
\hline & $(0.362)$ & $(0.329)$ & $(-0.982)$ & $(0.132)$ & $(0.207)$ \\
\hline \multirow{2}{*}{$\Delta$ buc $_{\mathrm{t}-1}$} & -0.4919 & -2.4271 & 0.4274 & 0.1872 & 0.2742 \\
\hline & $(-2.269)$ & $(-7.259)$ & (1.689) & $(1.479)$ & (2.198) \\
\hline \multirow{2}{*}{$\Delta \mathrm{buc}_{\mathrm{t}-2}$} & -0.0594 & 0.5894 & 0.1419 & -0.2099 & -0.1148 \\
\hline & $(-0.238)$ & (1.531) & $(0.487)$ & $(-1.441)$ & $(0.799)$ \\
\hline \multirow{2}{*}{$\Delta \mathrm{tsr}_{\mathrm{t}-1}$} & 0.7796 & 0.8786 & 0.2566 & -0.0339 & -0.1592 \\
\hline & $(2.902)$ & $(2.120)$ & $(0.818)$ & $(-0.216)$ & $(-1.029)$ \\
\hline \multirow{2}{*}{$\Delta \mathrm{tsr}_{\mathrm{t}-2}$} & 0.2755 & -0.5923 & -0.1103 & -0.0236 & -0.0455 \\
\hline & $(1.348)$ & $(-1.425)$ & $(-0.351)$ & $(-0.149)$ & $(-0.293)$ \\
\hline $\mathrm{R}^{-2}$ & 0.214 & 0.871 & 0.333 & 0.632 & 0.510 \\
\hline F-statistics & 5.761 & 118.49 & 9.71 & 31.05 & 19.18 \\
\hline Likelihood & -24.38 & -108.07 & -54.29 & 79.51 & 82.25 \\
\hline AIC & 0.377 & 1.244 & 0.687 & -0.699 & -0.727 \\
\hline
\end{tabular}


Table 6. Nigeria: Block exogeneity wald tests

\begin{tabular}{|c|c|c|c|c|c|c|}
\hline & agr & man & oil & buc & tsr & Joint \\
\hline agr & - & $16.347^{*}$ & 4.997 & $7.707^{*}$ & 4.931 & $25.23^{*}$ \\
\hline man & 2.699 & - & $64.243^{*}$ & $214.672^{*}$ & $161.886^{*}$ & $322.63^{*}$ \\
\hline oil & 0.962 & $20.934^{*}$ & - & $17.761^{*}$ & $13.749^{*}$ & $51.96^{*}$ \\
\hline buc & $13.031^{*}$ & $120.495^{*}$ & $6.215^{*}$ & - & 4.589 & $90.98^{*}$ \\
\hline tsr & $31.642^{*}$ & $20.791^{*}$ & 1.062 & 0.446 & - & $127.53^{*}$ \\
\hline
\end{tabular}

Note: * denotes statistical significance

Table 7. Nigeria: Variance decompositions

\begin{tabular}{|c|c|c|c|c|c|}
\hline Horizon (yrs) & agr & man & oil & buc & tsr \\
\hline \multicolumn{6}{|c|}{ Shock to agr explained by innovation in: } \\
\hline 1 & 100.00 & 0.00 & 0.00 & 0.00 & 0.00 \\
\hline 5 & 94.63 & 1.24 & 0.63 & 0.58 & 2.92 \\
\hline 10 & 94.79 & 1.23 & 0.53 & 0.45 & 2.99 \\
\hline \multicolumn{6}{|c|}{ Shock to man explained by innovation in: } \\
\hline 1 & 13.87 & 86.13 & 0.00 & 0.00 & 0.00 \\
\hline 5 & 18.08 & 57.12 & 6.83 & 13.71 & 4.27 \\
\hline 10 & 20.61 & 47.76 & 9.71 & 15.59 & 6.33 \\
\hline \multicolumn{6}{|c|}{ Shock to oil explained by innovation in: } \\
\hline 1 & 13.37 & 0.26 & 86.36 & 0.00 & 0.00 \\
\hline 5 & 23.99 & 8.01 & 66.58 & 1.38 & 0.03 \\
\hline 10 & 25.70 & 9.43 & 63.74 & 1.07 & 0.05 \\
\hline \multicolumn{6}{|c|}{ Shock to buc explained by innovation in: } \\
\hline 1 & 10.23 & 10.44 & 22.38 & 56.95 & 0.00 \\
\hline 5 & 17.76 & 9.03 & 20.87 & 52.18 & 0.15 \\
\hline 10 & 18.23 & 6.34 & 21.51 & 53.77 & 0.15 \\
\hline \multicolumn{6}{|c|}{ Shock to tsr explained by innovation in: } \\
\hline 1 & 27.06 & 3.89 & 17.95 & 29.38 & 21.71 \\
\hline 5 & 37.01 & 6.47 & 12.96 & 23.88 & 19.68 \\
\hline 10 & 38.74 & 6.63 & 12.25 & 23.09 & 19.29 \\
\hline
\end{tabular}




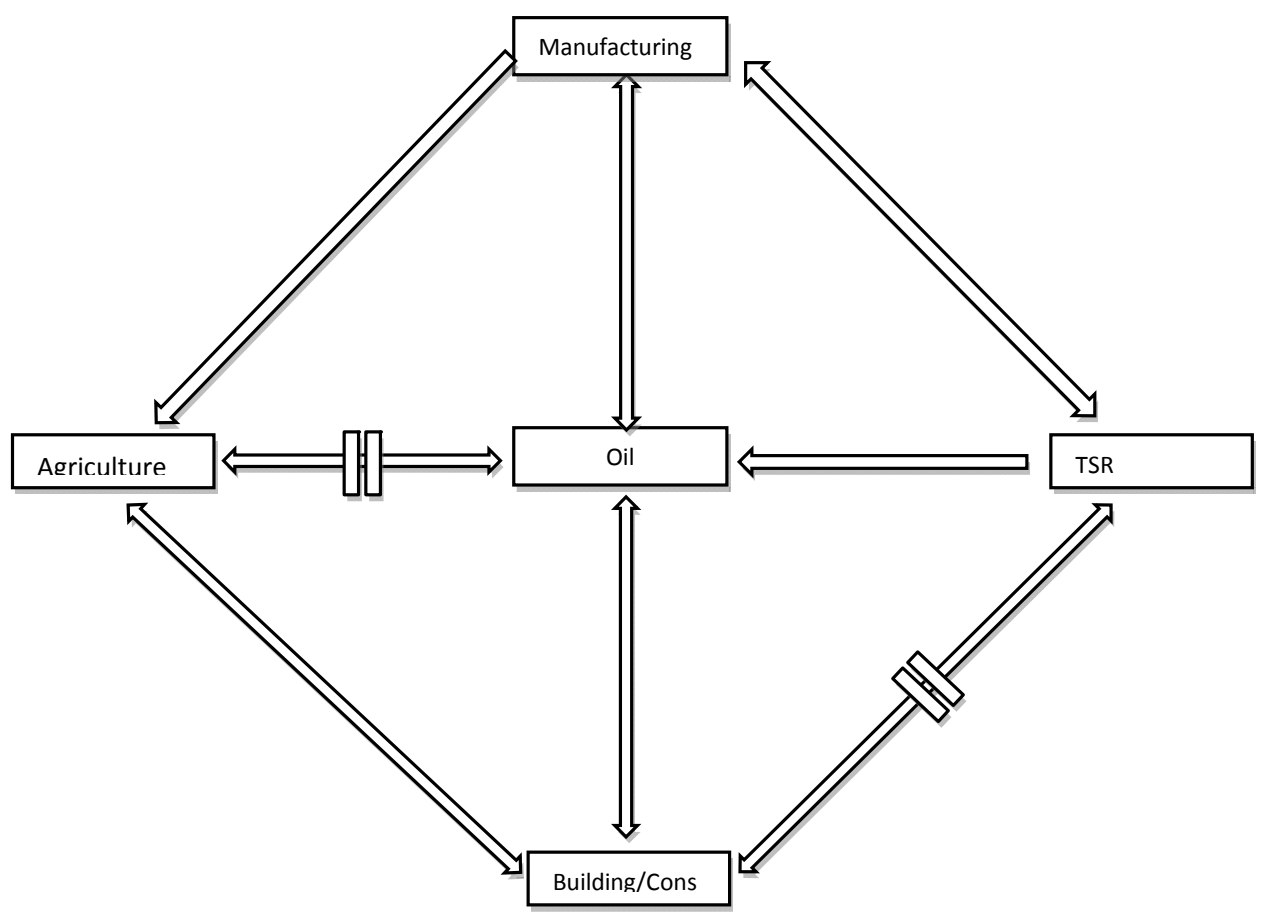

\section{Legend}

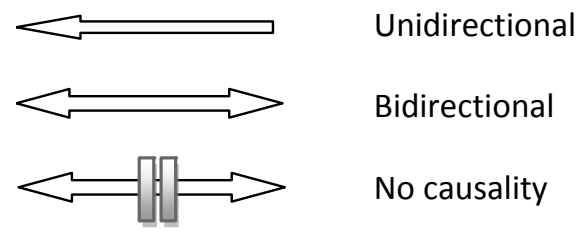

Figure 1 . Summary of the causality tests 

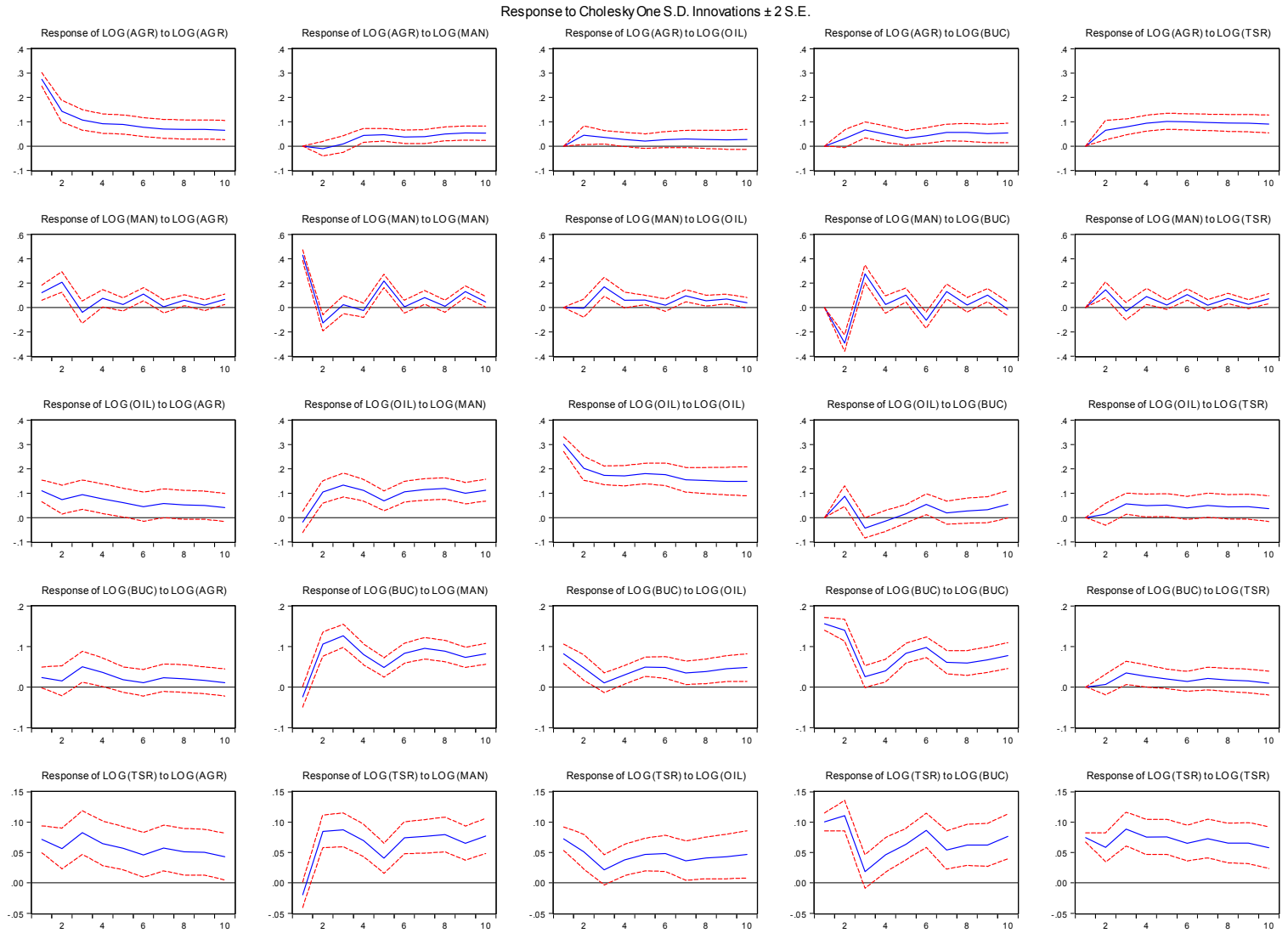

Figure 2. Impulse response analysis in VAR models 